\title{
Disseminated herpes zoster infection initially presenting with abdominal pain in patients with lymphoma undergoing conventional chemotherapy: A report of three cases
}

\author{
HITOMI SUMIYOSHI OKUMA ${ }^{1,2}$, YUKIO KOBAYASHI ${ }^{1}$, SHINICHI MAKITA ${ }^{1}$, HIDEAKI KITAHARA ${ }^{1}$, \\ SUGURU FUKUHARA ${ }^{1}$, WATARU MUNAKATA ${ }^{1}$, TATSUYA SUZUKI ${ }^{1}$, DAI MARUYAMA ${ }^{1}$ and KENSEI TOBINAI $^{1}$ \\ ${ }^{1}$ Department of Hematology, National Cancer Center Hospital, Tokyo 104-0045; ${ }^{2}$ Department of Medical Oncology, \\ Graduate School of Medicine, Chiba University Hospital, Chiba, Chiba 260-8670, Japan
}

Received January 26, 2015; Accepted March 15, 2016

DOI: $10.3892 / \mathrm{ol} .2016 .4683$

\begin{abstract}
Visceral disseminated varicella zoster virus (VZV) disease has a high mortality rate, and occurs in immunocompromised hosts, mostly subsequent to allogeneic stem cell transplantation. Only a few cases of this disease that onset during conventional chemotherapy in patients with lymphoma have been reported. The present study reports the cases of 3 patients with disseminated and visceral VZV infection undergoing treatment for follicular lymphoma, diffuse large B-cell lymphoma and peripheral T-cell lymphoma, not otherwise specified. All 3 patients presented with initial symptoms of abdominal pain, and 2 patients demonstrated syndrome of inappropriate antidiuretic hormone and hepatitis. All patients developed widespread cutaneous dissemination, and all had a low cluster of differentiation 4 cell count or lymphocyte count at the time of VZV diagnosis and at least 4 month prior. With intravenous systemic acyclovir therapy (Cases 1 and 3, $1500 \mathrm{mg} /$ day; Case 2, $750 \mathrm{mg} / \mathrm{day}$ ), the patients achieved complete recovery by day 14 of therapy. Visceral disseminated VZV infection is not limited to patients undergoing stem cell transplantation, and may present with abdominal pain with or without skin eruption. Visceral infection may take a poor clinical course, therefore, in patients with prolonged duration of low lymphocyte count and/or long-term use of steroids, the prophylactic use of acyclovir may be considered.
\end{abstract}

\section{Introduction}

Infection with disseminated varicella zoster virus (VZV), including cutaneous and visceral dissemination, occurs in

Correspondence to: Dr Yukio Kobayashi, Department of Hematology, National Cancer Center Hospital, 5-1-1 Tsukiji, Tokyo 104-0045, Japan

E-mail: ykkobaya@ncc.go.jp

Key words: lymphoma chemotherapy, infectious complications, varicella zoster virus, visceral dissemination, cutaneous dissemination recipients of autologous and allogeneic hematopoietic stem cell transplantation (HSCT) and in highly immunocompromised patients (1). The main risk factor for reactivation of VZV is profound disruption of the cellular immune response, rather than severity of neutropenia or depletion of circulating B cells (1). Allogeneic HSCT recipients carry a 20-50\% risk of developing any type of VZV infection $(1,2)$. The rate of VZV dissemination is $17-36 \%(3,4)$. However, cases of disseminated VZV in patients undergoing conventional chemotherapy are rare, with only case reports published, including a previous case report (5). Other previous cases with abdominal symptoms and syndrome of inappropriate antidiuretic hormone (SIADH) have additionally been reported (5-10). As disseminated VZV has a high mortality rate of up to $50 \%$ (11), anti-VZV therapy such as acyclovir should be immediately commenced. The recommended dose for adults with $\mathrm{VZ}$ is $800 \mathrm{mg}$ oral acyclovir five times daily, or $10 \mathrm{mg} / \mathrm{kg}$ intravenous acyclovir every 8 hours, although higher doses $(12-15 \mathrm{mg} / \mathrm{kg}$ ) are sometimes used for life-threatening infections, particularly in immunocompromised patients (1). VZV incidence increases markedly after 50 years of age, with two-thirds of herpes zoster (HZ) cases occurring in individuals aged $\geq 50$ years (12). One study provided an estimated case fatality rate of $2 / 100,000$ in patients aged between 45-65 years, and 61/100,000 in patients aged $>65$ years old (13). Although VZV-associated mortality rate is generally low, underlying comorbidities may increase the severity of the HZ episode and thus the risk of mortality (14). Recently, 2 additional patients presented with VZV infection, and the present study reports these 3 cases of disseminated $\mathrm{VZV}$ and analyzes the risk factors of VZV.

\section{Case report}

Case 1. A 61-year-old woman undergoing treatment for grade 2 follicular lymphoma, clinical stage IV, with a low International Prognostic Index (IPI) score, presented at the National Cancer Center Hospital (Tokyo, Japan) in December 2013, with severe upper abdominal pain that had lasted 3 days prior to admission. The patient had a long history of treatment for follicular lymphoma, as follows: 6 cycles of cyclophosphamide, doxorubicin, vincristine and prednisone [CHOP; 
$750 \mathrm{mg} / \mathrm{m}^{2}$ cyclophosphamide (day 1), $50 \mathrm{mg} / \mathrm{m}^{2}$ doxorubicin (day 1), $1.4 \mathrm{mg} / \mathrm{m}^{2}$ vincristine (day 1), and $100 \mathrm{mg}$ prednisone (days 1-5)] with rituximab; 1 course of rituximab monotherapy consisting of 8 cycles; 1 cycle of cyclophosphamide, vincristine, procarbazine and prednisone [C-MOPP; $1 \mathrm{mg}$ vincristine (days 1 and 8), $450 \mathrm{mg}$ cyclophosphamide (days 1 and 8), and $60 \mathrm{mg}$ prednisone (days 1,2 and 3); procarbazine was not administered]; 5 cycles of bendamustine (90 mg/m² on days 1 and 2); and 6 cycles of gemcitabine $\left(1000 \mathrm{mg} / \mathrm{m}^{2}\right.$ on days 1 and 15$)$. The patient was on day 5 of the second cycle of salvage C-MOPP prior to admission, and had also been taking $15 \mathrm{mg} /$ day prednisolone for tumor fever since 4 months prior to admission. The cluster of differentiation (CD) 4 cell count was 118 cells $/ \mathrm{mm}^{3}$ on admission, and had been $<200$ cells $/ \mathrm{mm}^{3}$ since 10 months prior (normal range, 400-1600 cells $/ \mathrm{mm}^{3}$ ) (Fig. 1). The serum immunoglobulin (Ig)G level was $289 \mathrm{mg} / \mathrm{dl}$ and had been $<400 \mathrm{mg} / \mathrm{dl}$ since 10 months prior (normal range, $842-1815 \mathrm{mg} / \mathrm{dl}$ ).

On examination, the patient had a slight fever of $37.4^{\circ} \mathrm{C}$, but other vital signs were normal. The abdomen was distended and tender and bowel sounds were diminished. Plain abdominal X-ray showed dilated small and large bowels, compatible with ileus, resulting in the suspension of oral intake. A computed tomography (CT) scan revealed the absence of perforated bowel, but showed wall thickening in one area of the transverse colon. Gastrointestinal endoscopy revealed no abnormalities.

On day 4 subsequent to admission, the patient demonstrated hyponatremia (122 mmol/l), low plasma osmolality (246 $\mathrm{mOsm} / \mathrm{kg} \mathrm{H}_{2} \mathrm{O}$ ) and high urine osmolality $(469 \mathrm{mOsm} / \mathrm{kg}$ $\mathrm{H}_{2} \mathrm{O}$ ), which is compatible with SIADH. At the same time, the total and direct bilirubin levels started to rise, which elevated to 4.9 and $3.1 \mathrm{mg} / \mathrm{dl}$, respectively. An abdominal echo showed no evidence of liver, bile tract, gallbladder or pancreas abnormalities. On day 5, the neutrophil counts decreased to $480 / \mathrm{mm}^{3}$ and the patient was treated with third generation cephalosporin antibiotics in case of masked bacterial infection. Following initiation of treatment with octreotide (300 $\mu \mathrm{g} / \mathrm{day})$ and opioids (fentanyl; $0.96 \mathrm{mg} /$ day), the abdominal pain and distention were relieved. On day 6 , the patient developed horizontal nystagmus, nausea and delirium. Radiographic findings of the head showed no focal lesions. Fever persisted, so antibiotics were switched to piperacillin/tazobactam. On day 9 , vesicular skin lesions appeared on the trunk and extremities of the patient, suggestive of disseminated $\mathrm{HZ}$ virus infection.

Upon starting intravenous acyclovir treatment at a dose of $1,500 \mathrm{mg} /$ day, the abdominal pain, SIADH and direct bilirubin levels of the patient improved. Polymerase chain reaction (PCR) for VZV of the peripheral blood taken prior to treatment revealed the presence of VZV. Subsequent to 14 days of acyclovir treatment, the skin lesions began crusting, and with relief of the symptoms of ileus, the patient began eating again. The patient was discharged on day 31 post-admission.

Case 2. A 72-year-old man diagnosed with peripheral T-cell lymphoma, not otherwise specified, serum human T-lymphotropic virus type I negative, clinical stage IVA, presented at the National Cancer Center Hospital (Tokyo, Japan) in June 2011, with a scattered vesicular rash accompanied by abdominal pain. The patient had been treated with 7 cycles of C-MOPP $[1 \mathrm{mg}$ vincristine (days 1 and 8), $650 \mathrm{mg} / \mathrm{m}^{2}$ cyclophosphamide (days 1 and 8), and $60 \mathrm{mg}$ prednisone (days 1,2 and 3); procarbazine was not administered] and had a past history of VZV infection limited to the left limb. The previous localized VZV infection occurred in March 2011, and lasted for 1 week. The infection was treated with oral valacyclovir at a dose of $1000 \mathrm{mg} 3$ times daily for 7 days. The patient had also been taking prednisolone at a dose of $20 \mathrm{mg} /$ day for 3 months prior to admission. The lymphocyte count of the patient was 160 cells $/ \mathrm{mm}^{3}$ on admission, and had been fluctuating between 200 and 800 cells $/ \mathrm{mm}^{3}$ for 1 year (normal range, 1098-2671 cells $/ \mathrm{mm}^{3}$ ). Although data on the CD4 cell count was not available, from the low overall lymphocyte count, it was considered that the CD4 cell count had been $<200$ cells $/ \mathrm{mm}^{3}$ for $\geq 6$ months (Fig. 2 ).

On examination, VZV infection was suspected at admission, and $750 \mathrm{mg} /$ day acyclovir, a reduced dose considering the decreased renal function of the patient, was administered immediately. On day 5 of treatment, the vesicles began to crust. Abdominal pain also diminished, and on day 14 of treatment, acyclovir therapy was terminated.

Case 3. This case has been previously reported in detail (5). A 65-year-old woman undergoing treatment for diffuse large B-cell lymphoma of the stomach, clinical stage III, low IPI score, presented at the National Cancer Center Hospital (Tokyo, Japan) in October 2004, with severe abdominal pain that had lasted 2 days prior to admission. The patient had had been treated with 3 cycles of CHOP $\left[750 \mathrm{mg} / \mathrm{m}^{2}\right.$ cyclophosphamide (day 1), $50 \mathrm{mg} / \mathrm{m}^{2}$ doxorubicin (day 1 ), $1.4 \mathrm{mg} / \mathrm{m}^{2}$ vincristine (day 1), and $100 \mathrm{mg}$ prednisone (days 1-5)], followed by locoregional radiation therapy at a total dose of $40.5 \mathrm{~Gy}$ (administered over 28 fractions), and the patient had completed the regimen 2 months prior to the present admission. The peripheral blood CD4 cell count was 135 cells $/ \mathrm{mm}^{3}$ and had been low for $>5$ months. The serum IgG level at admission was $962 \mathrm{mg} / \mathrm{dl}$, and had been 1527 mg/dl on February 12, 2004.

On admission, laboratory data revealed serum hyponatremia (122 mmol/l) with low serum osmolality $(262 \mathrm{mOsm} / \mathrm{kg}$ $\left.\mathrm{H}_{2} \mathrm{O}\right)$ and high urine osmolality $\left(532 \mathrm{mOsm} / \mathrm{kg} \mathrm{H}_{2} \mathrm{O}\right)$, and the patient was diagnosed with SIADH. On day 6 subsequent to admission, a subtle vesicular skin lesion on the abdomen and back of the patient developed, which indicated disseminated $\mathrm{HZ}$ virus infection. Subsequent to sampling the serum and cerebrospinal fluid (CSF) to test for VZV DNA, the patient was immediately treated with intravenous acyclovir $1,500 \mathrm{mg} / \mathrm{day}$.

The abdominal symptoms of the patient improved dramatically on the following day and laboratory data reflected the recovery of SIADH, when VZV DNA was found to be present in the serum and CSF. The skin lesions began to crust and the patient was discharged on day 14 .

\section{Discussion}

The present study reported 3 cases of unusual manifestation of disseminated VZV infection in patients with lymphoma. Theses cases were unusual due to the concomitant symptoms of visceral infection. All patients initially presented with abdominal pain and 2 patients had SIADH, while 1 patient also presented with acute hepatitis. Second, all patients were undergoing conventional chemotherapy alone without HSCT. The clinical characteristics and past therapy history for the present patients are listed in Tables I and II. 

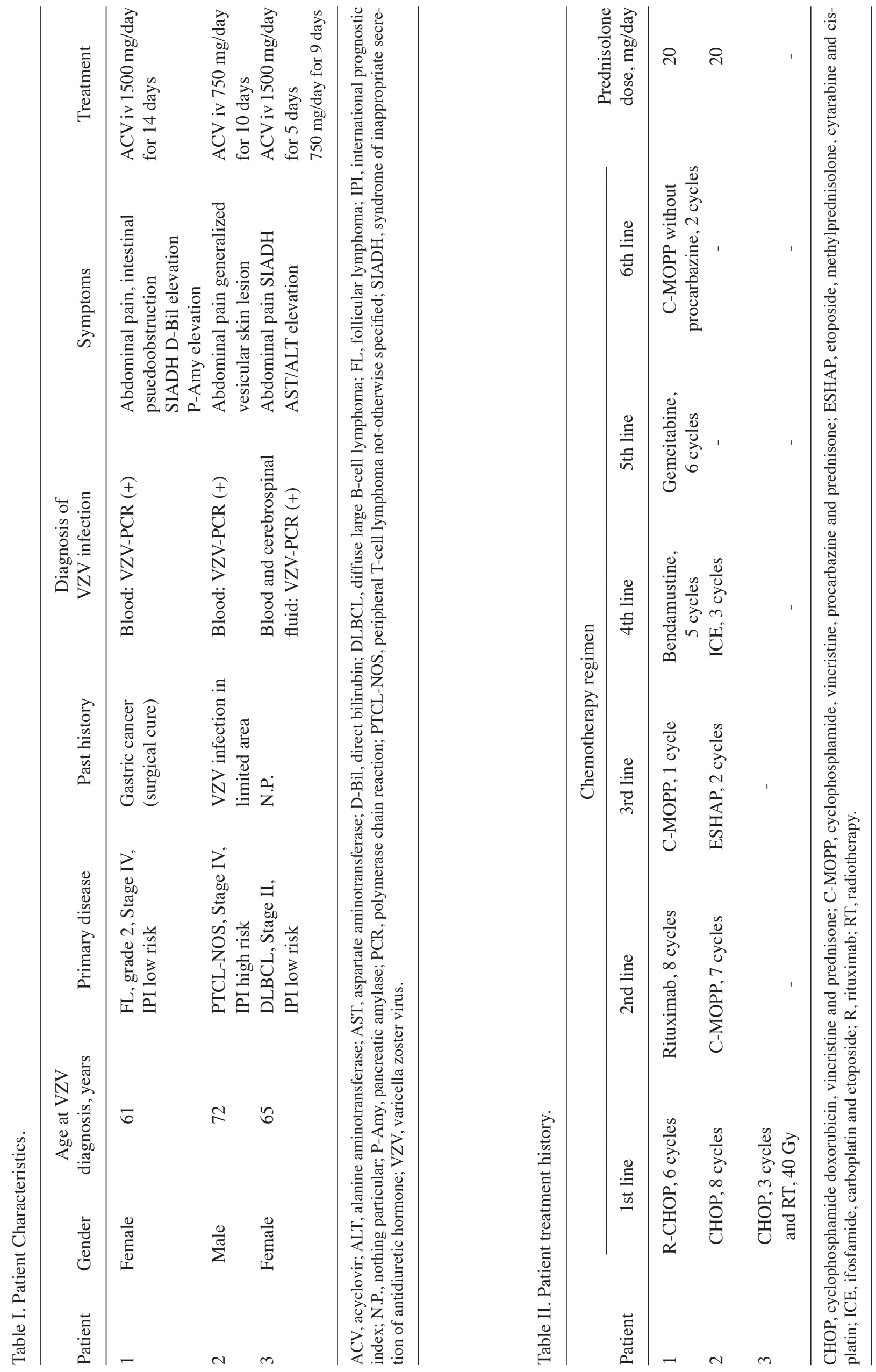


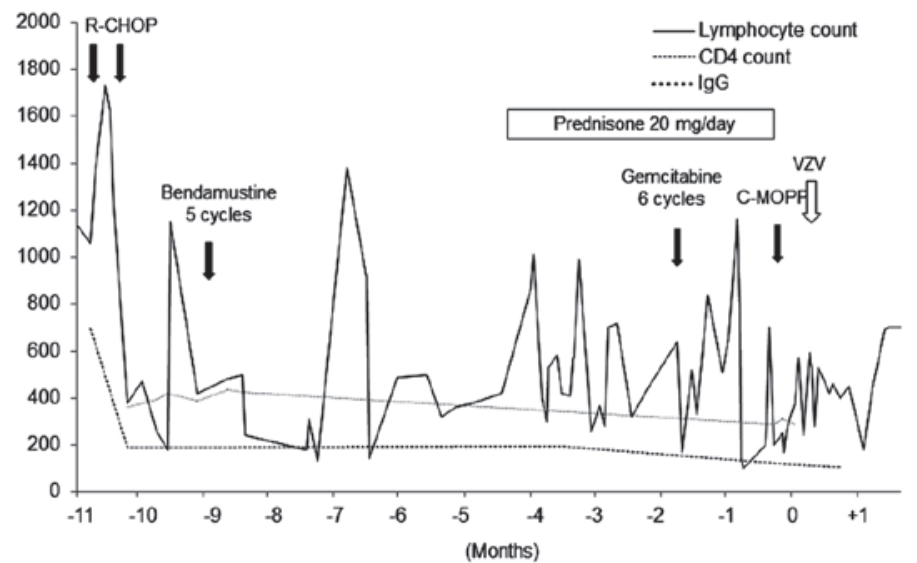

Figure 1. Clinical course of patient 1 . The CD4 count was 118 cells $/ \mathrm{mm}^{3}$ on admission, and had been $<200$ cells $/ \mathrm{mm}^{3}$ for the 10 months prior. The serum IgG level was $289 \mathrm{mg} / \mathrm{dl}$ and had been $<400 \mathrm{mg} / \mathrm{dl}$ for the 10 months prior. Lymphocyte count and CD4 count are measured in cells $/ \mathrm{mm}^{3}$ and IgG in mg/dl. CD4, cluster of differentiation 4; IgG, immunoglobulin G; R-CHOP, cyclophosphamide, doxorubicin, vincristine and prednisone with rituximab; C-MOPP, cyclophosphamide, vincristine, procarbazine and prednisone; VZV, varicella zoster virus.

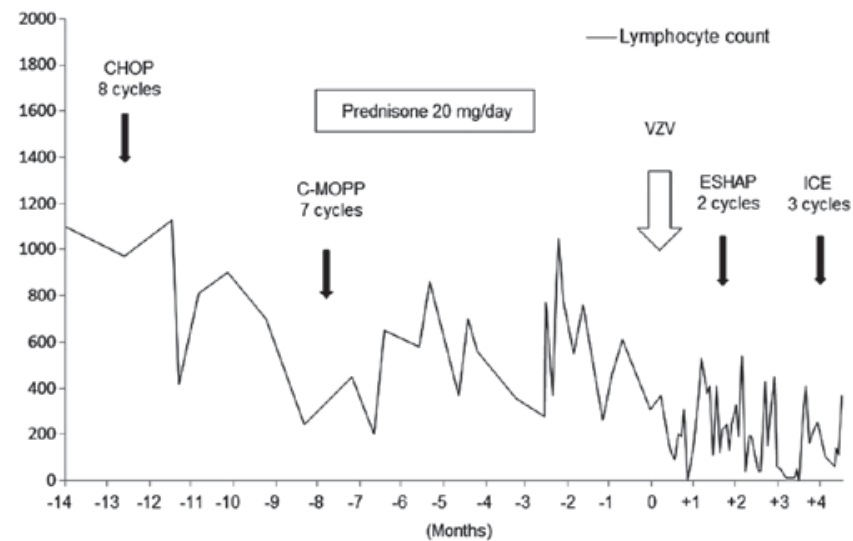

Figure 2. Clinical course of patient 2. The lymphocyte count was 160 cells $/ \mathrm{mm}^{3}$ on admission, and it had been fluctuating between 200 and 800 cells/mm for 1 year. Lymphocyte count is measured in cells $/ \mathrm{mm}^{3}$. CHOP, cyclophosphamide, doxorubicin, vincristine and prednisone; C-MOPP, cyclophosphamide, vincristine, procarbazine and prednisone; VZV, varicella zoster virus; ESHAP, etoposide, methylprednisolone, cytarabine and cisplatin; ICE, ifosfamide, carboplatin and etoposide.

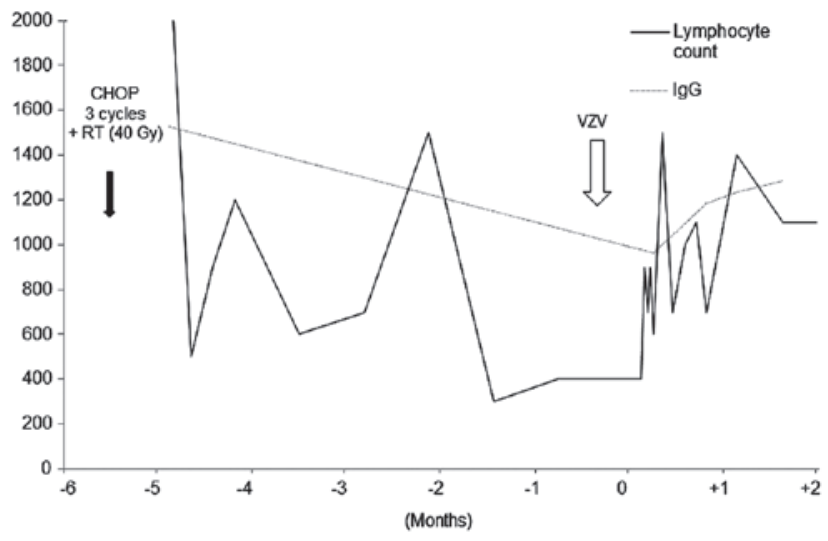

Figure 3. Clinical course of patient 3. The peripheral blood cluster of differentiation 4 count was $135 \mathrm{cells} / \mathrm{mm}^{3}$ on admission, and the total lymphocyte count had been low for $>5$ months. The IgG level had been $1527 \mathrm{mg} / \mathrm{dl}$ on February 12, 2004. Lymphocyte count is measured in cells/mm ${ }^{3} \mathrm{and} \mathrm{IgG} \mathrm{in} \mathrm{mg} / \mathrm{dl}$. CHOP, cyclophosphamide, doxorubicin, vincristine and prednisone; RT, radiotherapy; VZV, varicella zoster virus; IgG, immunoglobulin G.

Abdominal pain is considered to occur due to direct viral infection of the enteric nervous system (ENS), resulting from 2 different pathways. Viremia, in which circulating T cells carry VZV, and axonal transport from dorsal root ganglia are potential routes enabling VZV to gain access to the ENS. This may result in multiple intestinal disorders of unknown 
pathogenesis, such as irritable bowel syndrome, inflammatory bowel disease, idiopathic gastroparesis and idiopathic pseudo-obstruction (15). Acute colonic pseudo-obstruction is a severe and uncommon finding that is associated with immunodeficiency $(15,16)$.

The exact cause and mechanism of SIADH remains to be eludicated. However, this syndrome is hypothesized to result from central nervous system (CNS) infection, which may be responsible for stimulation of $\mathrm{ADH}$ release from the neurohypophyseal system $(6,17)$. Out of the present 2 patients with SIADH, patient 3 showed evidence of VZV infection in the CSF. In patient 1, although lumbar puncture was not performed, the patient presented with horizontal nystagmus, nausea and delirium, which suggested involvement of the CNS.

Abdominal pain and SIADH reflect viscerally disseminated viral disease, which may occur without evidence of cutaneous dissemination. There are studies reporting cases with abdominal symptoms and SIADH preceding skin rash (5-10). These viscerally disseminated VZV infections are sometimes fatal, with up to $50 \%$ mortality (11). Due to the high mortality rate, clinicians should consider VZV, and if VZV is suspected, treatment should be started as soon as possible upon sampling of VZV DNA (18). The present patients were treated successfully, prior to the result of the PCR test being obtained or prior to the symptoms becoming uncontrollable.

Disseminated VZV is observed more frequently in HSCT recipients compared with those patients undergoing conventional chemotherapy strategies. Risk factors of clinically relevant reactivation are considered to be profound disruption of the cellular immune response. This risk increases with intensity and duration of functional T-cell suppression (19). In HSCT recipients, the rate of VZV infection is $20-50 \%$ (1-3). Among those infected, the rate of visceral or cutaneous dissemination is $17-36 \%(3,4)$. However, although remaining a minority, disseminated VZV infection in those undergoing conventional chemotherapy is additionally accumulating $(5,8,20)$.

It was notable that all patients had low CD4 or lymphocyte counts for a long time and 2 patients had taken oral steroid therapy. Oral steroids, which can cause prolonged decreases in lymphocyte count, may have contributed to development of this unusual form of VZV.

Prophylactic antiviral therapy for HSCT recipients has been proposed (21-23) and low-dose acyclovir of $200 \mathrm{mg} /$ day or valacyclovir $500 \mathrm{mg} / \mathrm{day}, 3$ times/week for at least 1 year is warranted $(24,25)$. Previously, those treated with newer agents, such as alemtuzumab, bendamustine or the purine analogs fludarabine, 2-chlorodeoxyadenosine (2-CDA) and pentostatin, which cause major cellular immunodeficiency, were also indicated for antiviral prophylaxis (26). It is crucial to consider that visceral disseminated VZV may occur in patients undergoing conventional chemotherapy alone. Although cutaneous dissemination is not life-threatening, viscerally disseminated VZV seeding the intestine, liver, lung and CNS may be fatal (17).

In patients with a prolonged low lymphocyte count or long-term use of steroids, prophylactic acyclovir treatment may be required.

\section{References}

1. Arvin A and Abendroth A: VZV: Immunobiology and host response. In: Human Herpesviruses: Biology, Therapy, and Immunoprophylaxis. Arvin A, Campadelli-Fiume G, Mocarski E, Moore PS, Roizman B, Whitley R and Yamanishi K (eds). Cambridge University Press, Cambridge, pp700-712, 2007.

2. Blennow O, Fjaertoft G, Winiarski J, Ljungman P, Mattsson J and Remberger M: Varicella-zoster reactivation after allogeneic stem cell transplantation without routine prophylaxis-the incidence remains high. Biol Blood Marrow Transplant 20: 1646-1649, 2014.

3. Koc Y, Miller KB, Schenkein DP, Griffith J, Akhtar M, DesJardin J and Snydman DR: Varicella zoster virus infections following allogeneic bone marrow transplantation: Frequency, risk factors and clinical outcome. Biol Blood Marrow Transplant 6: 44-49, 2000.

4. Locksley RM, Flournoy N, Sullivan KM and Meyers JD: Infection with varicella-zoster virus after marrow transplantation. J Infect Dis 152: 1172-1181, 1985.

5. Ohara F, Kobayashi Y, Akabane D, Maruyama D, Tanimoto K, Kim SW, Watanabe T and Tobinai K: Abdominal pain and syndrome of inappropriate antidiuretic hormone secretion as a manifestation of visceral varicella zoster virus infection in a patient with non-Hodgkin's lymphoma. Am J Hematol 82: 416, 2007.

6. Ingraham IE Jr, Estes NA, Bern MM and DeGirolami PC: Disseminated varicella-zoster virus infection with the syndrome of inappropriate antidiuretic hormone. Arch Intern Med 143: 1270-1271, 1983

7. Vinzio S, Lioure B, Enescu I, Schlienger JL and Goichot B: Severe abdominal pain and inappropriate antidiuretic hormone secretion preceding varicella-zoster virus reactivation 10 months after autologous stem cell transplantation for acute myeloid leukaemia. Bone Marrow Transplant 35: 525-527, 2005.

8. Szabo F, Horvath N, Seimon S and Hughes T: Inappropriate antidiuretic hormone secretion, abdominal pain and disseminated varicella-zoster virus infection: An unusual triad in a patient 6 months post mini-allogeneic peripheral stem cell transplant for chronic myeloid leukemia. Bone Marrow Transplant 26: 231-233, 2000.

9. Rau R, Fitzhugh CD, Baird K, Cortez KJ, Li L, Fischer SH, Cowen EW, Balow JE, Walsh TJ, Cohen JI and Wayne AS: Triad of severe abdominal pain, inappropriate antidiuretic hormone secretion and disseminated varicella-zoster virus infection preceding cutaneous manifestations after hematopoietic stem cell transplantation: Utility of PCR for early recognition and therapy. Pediatr Infect Dis J 27: 265-268, 2008

10. Grant RM, Weitzman SS, Sherman CG, Sirkin WL, Petric M and Tellier R: Fulminant disseminated Varicella Zoster virus infection without skin involvement. J Clin Virol 24: 7-12, 2002.

11. David DS, Tegtmeier BR, O'Donnell MR, Paz IB and McCarty TM: Visceral varicella-zoster after bone marrow transplantation: Report of a case series and review of the literature. Am J Gastroenterol 93: 810-813, 1998.

12. Yawn BP, Saddier P, Wollan PC, St Sauver JL, Kurland MJ and Sy LS: A population-based study of the incidence and complication rates of herpes zoster before zoster vaccine introduction. Mayo Clin Proc 82: 1341-1349, 2007.

13. Brisson $\mathrm{M}$ and Edmunds WJ; Epidemiology of varicella-zoster virus in England and Wales. J Med Virol 70 (Suppl 1): S9-S14, 2003.

14. Gil A, Gil R, Alvaro A, San Martín M and González A: Burden of herpes zoster requiring hospitalization in Spain during a seven-year period (1998-2004). BMC Infect Dis 9: 55, 2009.

15. Chen JJ, Gershon AA, Li Z, Cowles RA and Gershon MD: Varicella zoster virus (VZV) infects and establishes latency in enteric neurons. J Neurovirol 17: 578-589, 2011.

16. Pui JC, Furth EE, Minda J and Montone KT: Demonstration of varicella-zoster virus infection in the muscularis propria and myenteric plexi of the colon in an HIV-positive patient with herpes zoster and small bowel pseudo-obstruction (Ogilvie's syndrome). Am J Gastroenterol 96: 1627-1630, 2001.

17. Moses A and Streeten D: Disorders of the neurohypophysis Syndromes associated with vasopressin excess. In: Harrison's Principles of Internal Medicine. Isselbacher K, Braunwald E, Wilson J, Martin J, Fauci A and Kasper D (eds). Vol 2. 13th edition. McGraw-Hill, New York, NY, pp1928-1930, 1994. 
18. Ishizaki Y, Tezuka J, Ohga S, Nomura A, Suga N, Kuromaru R, Kusuhara K, Mizuno Y, Kasuga N and Hara T: Quantification of circulating varicella zoster virus-DNA for the early diagnosis of visceral varicella. J Infect 47: 133-138, 2003.

19. Storek J, Gooley T, Witherspoon RP, Sullivan KM and Storb R: Infectious morbidity in long-term survivors of allogeneic marrow transplantation is associated with low CD4 T cell counts. Am J Hematol 54: 131-138, 1997.

20. Okamoto A, Abe A, Okamoto M, Kobayashi T, Terazawa T, Inaguma Y, Tokuda M, Yanada M, Morishima S, Kanie T, et al: Severe hepatitis associated with varicella zoster virus infection in a patient with diffuse large B cell lymphoma treated with rituximab-CHOP chemotherapy. Int J Hematol 96: 516-520, 2012.

21. Kanda Y, Mineishi S, Saito T, Saito A, Yamada S, Ohnishi M, Chizuka A, Niiya H, Suenaga K, Nakai K, et al: Long-term low-dose acyclovir against varicella-zoster virus reactivation after allogeneic hematopoietic stem cell transplantation. Bone Marrow Transplant 28: 689-692, 2001.

22. Erard V, Guthrie KA, Varley C, Heugel J, Wald A, Flowers ME, Corey L and Boeckh M: One-year acyclovir prophylaxis for preventing varicella-zoster virus disease after hematopoietic cell transplantation: No evidence of rebound varicella-zoster virus disease after drug discontinuation. Blood 110: 3071-3077, 2007.

23. Kawamura K, Wada H, Yamasaki R, Ishihara Y, Sakamoto K, Ashizawa M, Sato M, Machishima T, Terasako K, Kimura S, et al: Prophylactic role of long-term ultra-low-dose acyclovir for varicella zoster virus disease after allogeneic hematopoietic stem cell transplantation. Int J Infect Dis 19: 26-32, 2014.
24. Oshima K, Takahashi T, Mori T, Matsuyama T, Usuki K, Asano-Mori Y, Nakahara F, Okamoto S, Kurokawa M and Kanda Y: One-year low-dose valacyclovir as prophylaxis for varicella zoster virus disease after allogeneic hematopoietic stem cell transplantation. A prospective study of the Japan Hematology and Oncology Clinical Study Group. Transpl Infect Dis 12: 421-427, 2010.

25. Asano-Mori Y, Kanda Y, Oshima K, Kako S, Shinohara A, Nakasone H, Sato H, Watanabe T, Hosoya N, Izutsu K, et al: Long-term ultra-low-dose acyclovir against varicella-zoster virus reactivation after allogeneic hematopoietic stem cell transplantation. Am J Hematol 83: 472-476, 2008.

26. Sandherr M, Einsele H, Hebart H, Kahl C, Kern W, Kiehl M, Massenkeil G, Penack O, Schiel X, Schuettrumpf S, et al: Antiviral prophylaxis in patients with haematological malignancies and solid tumours: Guidelines of the Infectious diseases working party (AGIHO) of the German society for hematology and oncology (DGHO). Ann Oncol 17: 1051-1059, 2006. 